\title{
Flow injection analysis for the photometric determination of promethazine-HCl in pure and pharmaceutical preparation via oxidation by persulphate using Ayah 3SX3-3D solar micro photometer
}

\author{
Issam M. A. Shakir *
}

Nagam S. Turkey*

Received 14, November, 2012

Accepted 28, February, 2013

\begin{abstract}
:
The first flow injection spectrophotometric method is characterized by its speed and sensitivity which have been developed for the determination of promethazine- $\mathrm{HCl}$ in pure and pharmaceutical preparation. It is based on the in situ detection of colored cationic radicals formed via oxidation of the drug with sodium persulphate to pinkish-red species and the same species was determined by using homemade Ayah 3SX3-3D solar flow injection photometer. Optimum conditions were obtained by using the high intensive green light emitted diode as a source. Linear dynamic range for the absorbance versus promethazine- $\mathrm{HCl}$ concentration was 0-7 mmol. $\mathrm{L}^{-1}$, with the correlation coefficient (r) was 0.9904 while the percentage linearity $\left(\mathrm{r}^{2} \%\right)$ was $98.09 \%$. the L.O.Q was $3.97 \mu \mathrm{g} / \mathrm{sample}$, while L.O.D ( $\left./ \mathrm{N}=3\right)=$ $0.2407 \mu \mathrm{g} / \mathrm{sample}\left(5 \mu \mathrm{mol} . \mathrm{L}^{-1}\right)$ from the stepwise dilution for the minimum concentration of lowest concentration in the linear dynamic range of the calibration graph. The R.S.D\% at 2 mmol. $\mathrm{L}^{-1}$ promethazine- $\mathrm{HCl}$ is less than $1 \%$ (eight replicates) using $150 \mu \mathrm{L}$ sample volume. Throughput 30 sample.hr $^{-1}$. The method was applied successfully for the determination of promethazine- $\mathrm{HCl}$ in pharmaceutical preparation. By using paired t-test it was shown that there was no significant difference between the proposed method and official method and on that basis the new method can be accepted as an alternative analytical method.
\end{abstract}

Key words: Flow injection analysis, promethazine hydrochloride, spectrophotometric.

\section{Introduction:}

Promethazine-HCl, (2RS)-N,N-dimethyl-(10H-phenothiazin-10-yl)

propan-2-amine hydrochloride is commonly known as neuroleptic tranquilizer and commonly used as a sedative, antihistamine, antiemetic and anaesthetic. (Fig.1.)<smiles>CC(C)CN1c2ccccc2Sc2ccccc21</smiles>

Fig.1: structure of promethazine-HCl
It is a white or faintly yellowish crystalline powder, very soluble in water and in alcohol [1]. Many analytical techniques have been employed for the determination of promethazine-HCl. Spectrophotometric procedures are based on the chemical oxidation of promethazine- $\mathrm{HCl}$ to form colored radical cation using oxidizing agents, such as cerium(IV) arsenite which is used as a strongly oxidizing solid-phase reactor[2], molybdophosphoric acid[3], iron (III) was used as oxidant and the iron (II) formed was

\footnotetext{
*Chemistry department - college of science - university of Baghdad - Iraq.
} 
measured as its 1,10-phenanthroline complex[4], iodic acid in the presence of sulphuric or phosphoric acid medium yielding a red colored product [5] and potassium persuphate to give a colored complex [6]. Various other methods, like oxidative-coupling reaction with 3-methyl-2-benzothiazolinone hydrazone for determination of some anti-allergic agents [7], potentiometric sensor [8], turbidimetric method for determination of promethazine hydrochloride with bromophenol blue [9], nephelometric titration[10]. Titrimetric procedures are based on the redox properties of some N-substituted phenothiazine derivatives with hexaamminecobalt (III)tri-carbonatocobaltate (III)[11]. Spectrofluorometric methods based on oxidation of promethazine- $\mathrm{HCl}$ to form its fluorescent sulphoxide derivative $(12,13)$. Chemiluminescence reaction coupled with flow injection analysis, have also been employed $[14,15]$. Few methods applying flow injection have been reported: based on the use of a ceric ions in a sulphuric acid medium as an oxidant [16], other uses $\mathrm{Fe}(\mathrm{III}) / \mathrm{Fe}(\mathrm{II})$ as a redox system with biamperometric flow-through detector for the determination of phenothiazine derivatives in several commercial pharmaceutical preparations[17].

The present work is concerned with the determination of promethazine $-\mathrm{HCl}$ with the aid of a flow injection technique. The method is based upon the oxidation of promethazine- $\mathrm{HCl}$ by means of potassium persulphate in an aqueous medium. The oxidation product yields a pinkish red color measured at $515 \mathrm{~nm}$. The procedure is simple, rapid and is proposed for the control analysis of the drug in pure and pharmaceutical preparations as an alternative analytical procedure.

\section{Materials and Methods:} Chemicals

All chemicals used were of analytical reagent grade. Distilled water was used to prepare all the solutions. Freshly prepared solutions were always used. Standard solution $(\mathrm{w} / \mathrm{v})$ of promethazine- $\mathrm{HCl}$ $\left(\mathrm{C}_{17} \mathrm{H}_{20} \mathrm{~N}_{2} \mathrm{~S}, \mathrm{HCl}, 320.9\right.$ g.mol ${ }^{-1}$, SDI, $10 \mathrm{mmol} . \mathrm{L}^{-1}$ ) was prepared by dissolving $0.3209 \mathrm{gm}$ of the drug in distilled water and diluting to the mark with the same in a $100 \mathrm{ml}$ calibrated flask to give a stock solution, which was diluted further as required. A stock solution of sodium persulphate $\left(\mathrm{Na}_{2} \mathrm{~S}_{2} \mathrm{O}_{8}, 238.10\right.$ g.mol ${ }^{-1}, \mathrm{BDH}, 100$ mmol.L ${ }^{-1}: 5.9525 \mathrm{~g} / 250 \mathrm{ml}$ distilled water. Nitric acid, 1 mol.L $\mathrm{L}^{-1}$,Dilute 128 $\mathrm{ml}$ of $70 \% \mathrm{HNO}_{3}$ (sp.gr. $1.42 \mathrm{~g} \cdot \mathrm{ml}^{-1}$, $\mathrm{BDH}$ ) with water to $2 \mathrm{~L}$ in a calibrated flask, Sulphuric acid, 1 mol. $\mathrm{L}^{-1}$. Dilute $111 \mathrm{ml}$ of $96 \% \mathrm{~m} / \mathrm{m} \mathrm{H}_{2} \mathrm{SO}_{4}$ (sp.gr. 1.84 g. $\left.\mathrm{ml}^{-1} ; \mathrm{BDH}\right)$ with water in a $2 \mathrm{~L}$ calibrated flask. Hydrochloric acid,1 mol. $\mathrm{L}^{-1}$. Dilute $176.50 \mathrm{ml}$ of $35 \% \mathrm{HCl}$ (sp.gr. 1.18 g.ml ${ }^{-1}, \mathrm{BDH}$ with water in a $2 \mathrm{~L}$ calibrated flask.

\section{Apparatus and manifold:}

The flow system used for the determination of promethazine$\mathrm{HCl}$,shown schematically in fig. 2.

A peristaltic pump:one channel, variable speed (Ismatec, Switzerland), 6-port medium pressure injection valve (IDEX corporation, USA) with a sample loop $(0.7 \mathrm{~mm}$ i.d., Teflon, variable lengths) used for sample injection. The instrument response was measured by Ayah 3SX3-3D solar FI photometer (homemade) by using super bright blue, green and red light emitted diode (LED) as source with a detection using solar cell [18]. The output signals were recorded by potentiometric recorder (Siemens, Germany, range (1-500) $\mathrm{mV}$ or (1-500) Volt. Peak height was measured for each signals. UV-Vis (Cary-100 conc) 
spectrophotometer digital double beam type (Japan) was also used to scan the spectrum of product of reactants using $1 \mathrm{~cm}$ glass cell.

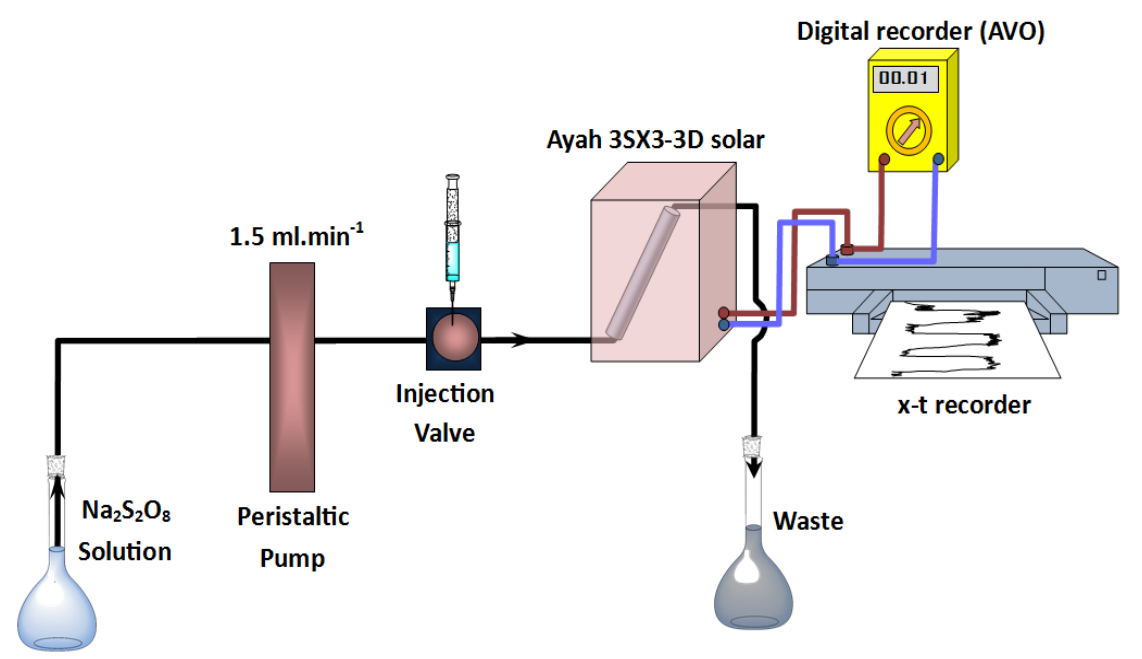

Fig. 2: Schematic diagram of flow injection analysis system.

\section{Methodology:}

The whole reaction manifold
system for promethazine-HCl determination via directly oxidizes promethazine- $\mathrm{HCl}$ to colored cationic radical with sodium persulphate is shown in fig. 2. The manifold system is simple and it is composed of one line supplied sodium persulphate $(30$ mmol. $\mathrm{L}^{-1}$ ) at $1.5 \mathrm{ml} \cdot \mathrm{min}^{-1}$ which leads to the injection valve to carry promethazine- $\mathrm{HCl}$ sample of $150 \mu \mathrm{L}$ (loop length 39 with $0.7 \mathrm{~mm}$ I.D). The absorbance peak of the resulting pinkish-red product is followed by using Ayah 3SX3-3D solar photometer and the variation of response was monitored by using green light emitted diode (LED) throughout the reaction. Each solution was assayed in triplicate. A proposed mechanism of oxidation of promethazine- $\mathrm{HCl}$ in aqueous medium is presented in fig.[ [19]

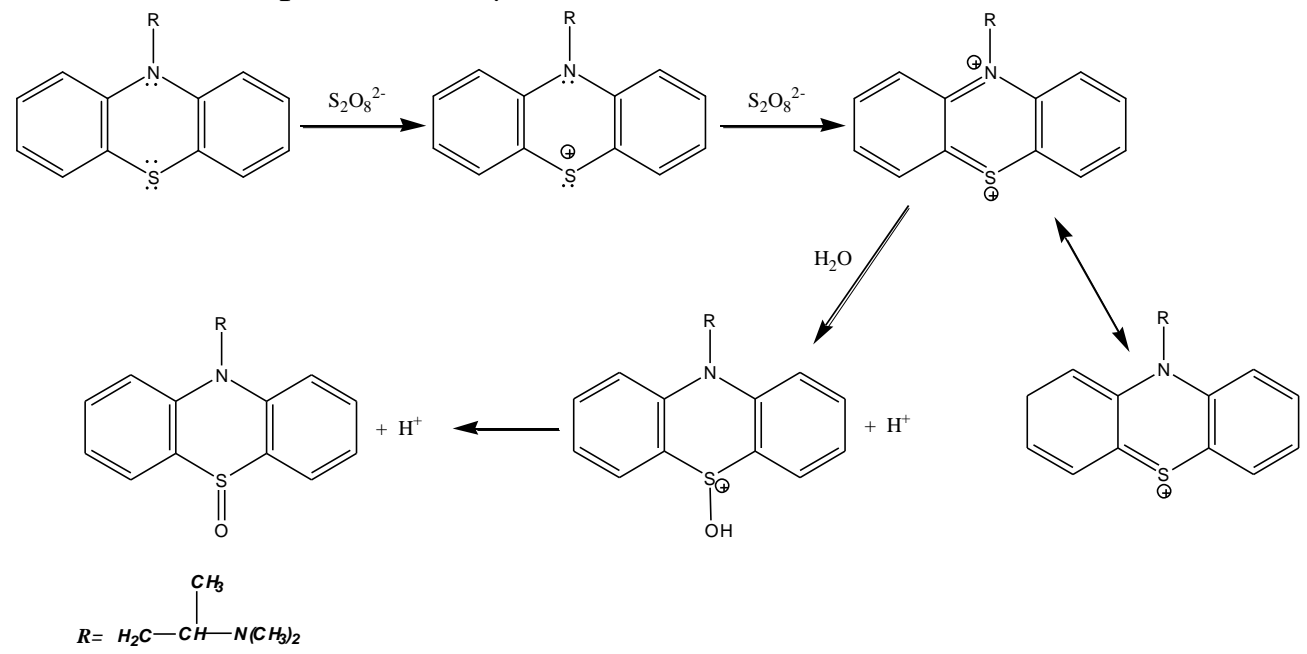

Fig. 3: Proposed mechanism of reaction between promethazine-HCl and sodium persulphate. 
Results and Discussion: spectroscopic study of promethazine $-\mathrm{HCl}-\mathrm{S}_{2} \mathrm{O}_{8}{ }^{2-}$ system.

A dilute aqueous solution of promethazine- $\mathrm{HCl}$ when mixed with sodium persulphate as oxidizing agent an intense pinkish-red colour product was formed immediately, the product shows a maximum absorption at 515 $\mathrm{nm}$ against reagent blank (promethazine- $\mathrm{HCl}$ ) as shown in fig. 4 .

The colour product of the oxidized species formed by promethazine- $\mathrm{HCl}$ as mentioned previously was measured by using Ayah 3SX3-3D solar FI photometer at three different light emitted diode (LED) [blue $(470 \mathrm{~nm})$, green $(525 \mathrm{~nm})$, and red $(635 \mathrm{~nm})]$, a maximum response measured in $\mathrm{mV}$ obtained when using the high intensity green light emitted diode $(525 \mathrm{~nm})$ as source as shown in fig. 5 .

Optimum conditions for oxidation of promethazine-HCl with sodium persulphate by using homemade Ayah 3SX3-3D solar FI photometer.

\section{Chemical variable}

- Effect of sodium persulphate concentration:

A series of sodium persulphate solutions were prepared by ranging (550) $\mathrm{mmol} . \mathrm{L}^{-1}$ to establish the optimum concentration that can be used. The study was conducted that $30 \mathrm{mmol}^{-1}$ of sodium persulphate was necessary to achieve the maximum colour intensity of the product (fig. 6). Above and below this concentration, the colour intensity diminished. The probable mechanism is that sodium persulphate instantaneously oxidizes the promethazine- $\mathrm{HCl}$ at room temperature giving a pinkish-red coloured species that is believed to be a radical cation. Most probably, the excess of persulphate causes an irreversible oxidation of the coloured product to a colourless sulphoxide with the loss of one or more electrons.

- Effect of acidic media on the absorbance of promethazine-HCl$\mathrm{S}_{2} \mathrm{O}_{8}{ }^{2-}$ system:

The oxidation of promethazine$\mathrm{HCl}$ with persulphate was studied in different acidic media (nitric, hydrochloric and Sulphuric acid) at 30 mmol. $\mathrm{L}^{-1}$ concentration in addition to the aqueous phase medium yielding immediately a pinkish-red colour. The results are depicted in fig. 7 . In which that nitric acid increases absorbance which might be explained as it is a powerful oxidizing agent which increases the coloured species; in addition to persulphate effect. While using hydrochloric acid absorbance is dcreased due to the reducing effect of the chloride ions which in turn consume part of the available of persulphate ion. While for Sulphuric acid no significant difference was found compared to the aqua medium. On the basis of the outcome of the results obtained from this section; aqueous medium was chosen as the optimum medium to conduct the reaction pattern. 


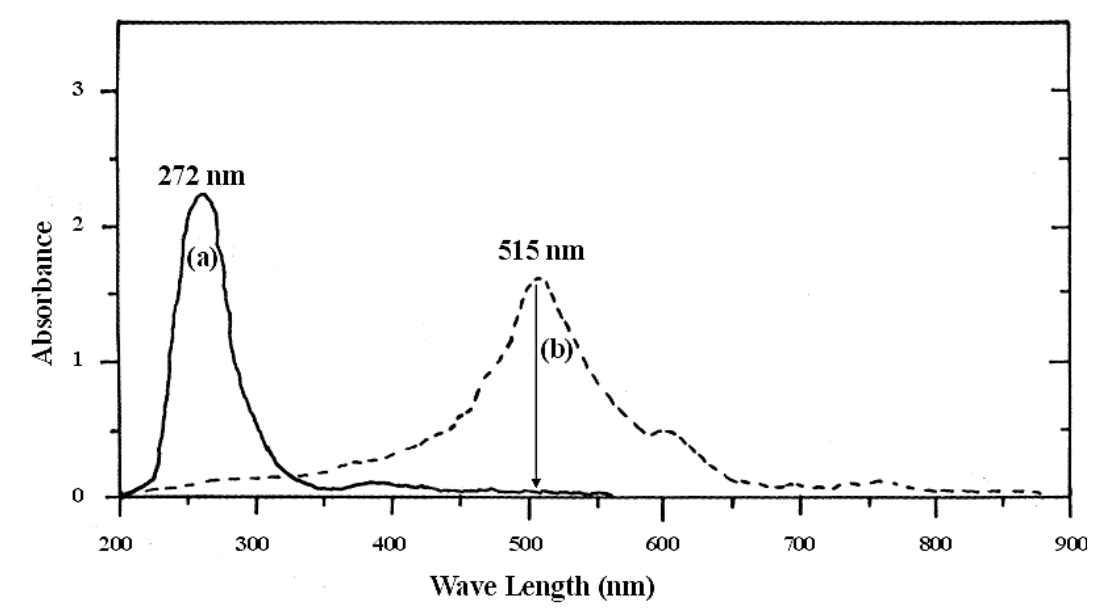

Fig. 4: Absorbance spectra for pinkish-red species formed by promethazine-HCl $\left(1 \mathrm{mmol.l^{-1 }}\right)-\mathrm{S}_{2} \mathrm{O}_{8}{ }^{2}\left(7 \mathrm{mmol.l^{-1 }}\right)$ system; a: Absorbance spectra (-) for promethazine-HCl, b: Absorbance spectra (---) for promethazine-HCl-S $\mathrm{S}_{2} \mathrm{O}_{8}^{-2}$ system using promethazine- $\mathrm{HCl}$ as a reference blank.

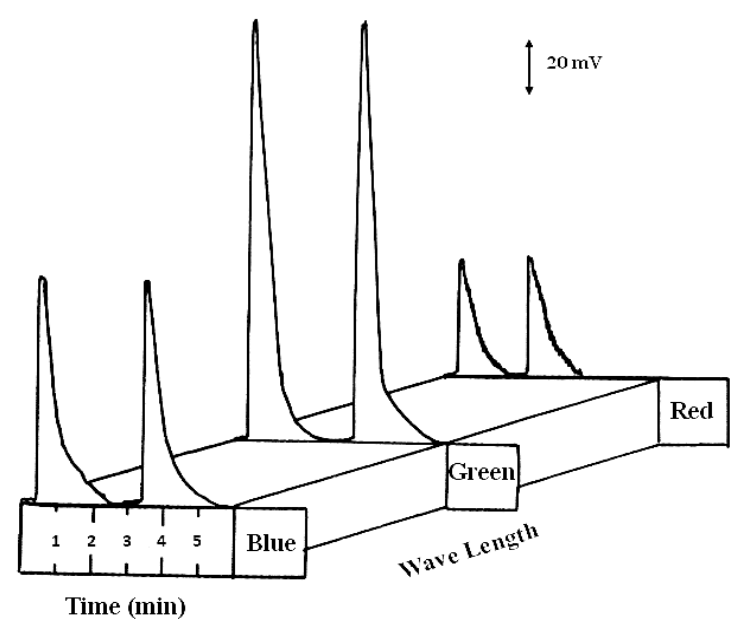

Fig. 5: A maximum response measured in $\mathrm{mV}$ of pinkish-red species formed by injection $100 \mu \mathrm{L}\left(1 \mathrm{mmol} . \mathrm{L}^{-1}\right)$ of promethazine-HCl at three different light emitted diode which is blue $(470 \mathrm{~nm})$, green $(525 \mathrm{~nm})$ and red $(635 \mathrm{~nm})$ as source using homemade Ayah 3SX3-3D solar FI photometer.

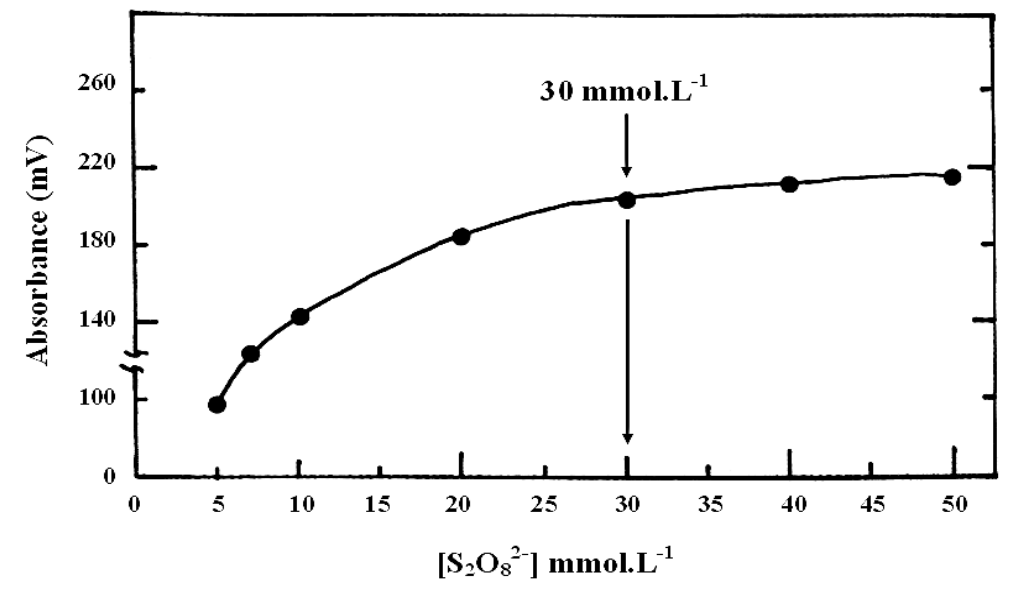

Fig. 6: Effect of variation of sodium persulphate concentration on absorbance using promethazine-HCl $\left(2 \mathrm{mmol} . \mathrm{L}^{-1}\right)-\mathrm{S}_{2} \mathrm{O}_{8}{ }^{2-}$, with sample volume $100 \mu \mathrm{L}$, flow rate: $1 \mathrm{ml} . \mathrm{min}^{-1}$. 


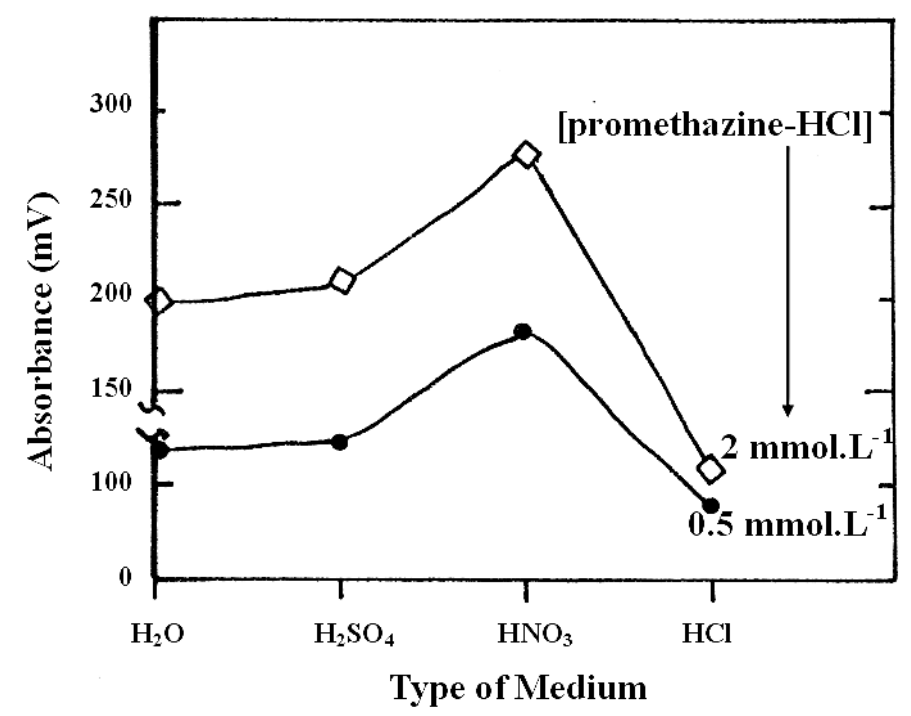

Fig. 7: Effect of the acid medium on the oxidation of promethazine-HCl (2 mmol. $\left.\mathrm{L}^{-1}\right)$ with $\mathrm{S}_{2} \mathrm{O}_{8}{ }^{2-}\left(30 \mathrm{mmol} . \mathrm{L}^{-1}\right)$, each of acid at 30 mmol. $\mathrm{L}^{-1}$ concentration.

\section{Physical variables}

- Effect of flow rate of sodium persulphate:

A set of experimental was carried out for the optimization of the preferred flow rate of sodium persulphate as a carrier $\left(30 \mathrm{mmol} . \mathrm{L}^{-1}\right)$ that extent (0.9-3) ml.min ${ }^{-1}$ using 100 $\mu \mathrm{L}$ of $2 \mathrm{mmol} . \mathrm{L}^{-1}$ of promethazine- $\mathrm{HCl}$ and 15 second as purge time for the sample segment. The results obtained were summarized in fig. 8. A, B. It was noticed that at slow flow rate, there is increase in dilution and dispersion which might cause an increase in base of response $\left(\Delta \mathrm{t}_{\mathrm{B}}\right)$ as show in fig. $8 \mathrm{~A}$. while at higher flow rate $\left(>1.5 \mathrm{ml} . \mathrm{min}^{-1}\right.$ in fig. $8 \mathrm{~A}$ ), although the effect on physical parameter was not very crucial on the response obtaining regular responses and sharp maxima but it is not very high due to departure of reactants from measuring cell prior to completion of reaction. Fig. $8 \mathrm{~B}$ shows that an increase in the flow rate led to reach the coloured species to the measuring cell in a minimum time $(\mathrm{T})$, therefore a flow rate of $1.5 \mathrm{ml} \cdot \mathrm{min}^{-1}$ was adopted for promethazine- $\mathrm{HCl}$ determination to obtain a maximum response and less $\Delta \mathrm{t}_{\mathrm{B}}$ as shown in fig. $8 \mathrm{~A}$.
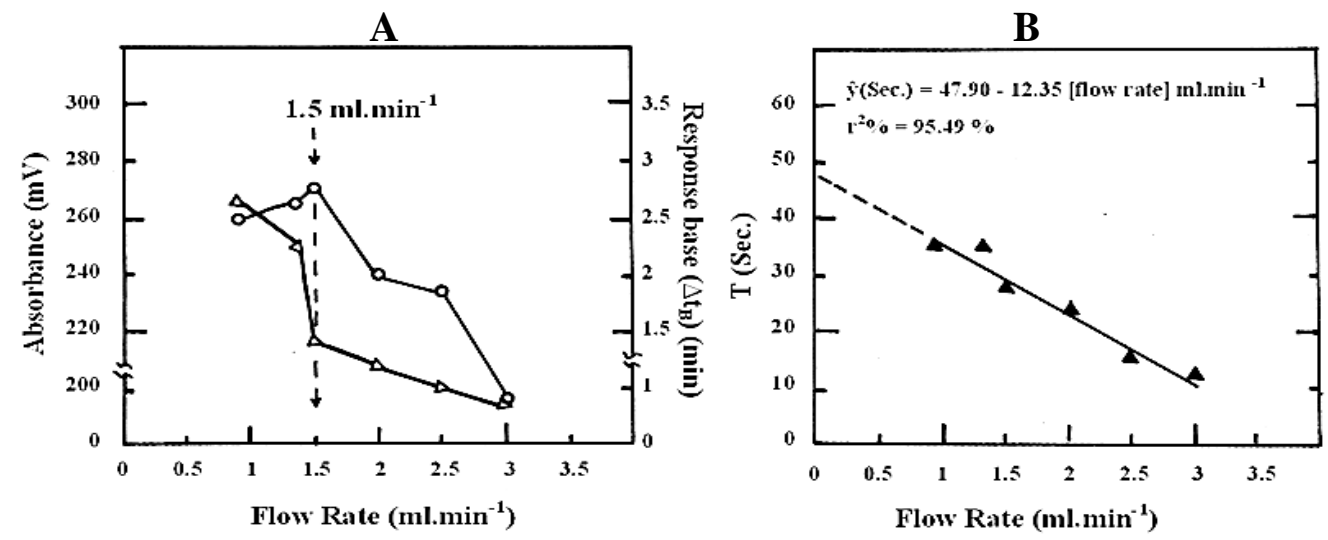

Fig. 8: Effect of variation of flow rate on:

A- (-०-): Absorbance for pinkish-red species $\&(-\Delta-)$ response base width $\left(\Delta t_{B}\right)$.

B- $T$ (time for the departure of sample segment from injection valve reaching to the measuring cell).

Using parameter: promethazine-HCl $\left(2\right.$ mmol.L $\left.{ }^{-1}\right)-\mathrm{S}_{2} \mathrm{O}_{8}{ }^{2-}\left(30 \mathrm{mmol} . \mathrm{L}^{-1}\right)$, sample volume $100 \mu \mathrm{L}$. 


\section{- Effect of sample volume:}

Using the optimum flow rate of $1.5 \mathrm{ml} . \mathrm{min}^{-1}$ with a various volumes (76-190) $\mu \mathrm{L}$ were injected using open valve mode i.e. allowance for concentration purge of sample segment from the sample loop in the injection valve. The data obtained were plotted as shown in fig. 9 A showing that the optimum sample volume is $150 \mu \mathrm{L}$ for better response as shown in fig. $9 \mathrm{~B}$, while increasing sample volume more than $150 \mu \mathrm{L}$ gave broadening of the base as well as the peak maxima which was most probably attributed to continuous long time duration of colour segment in front of detector.
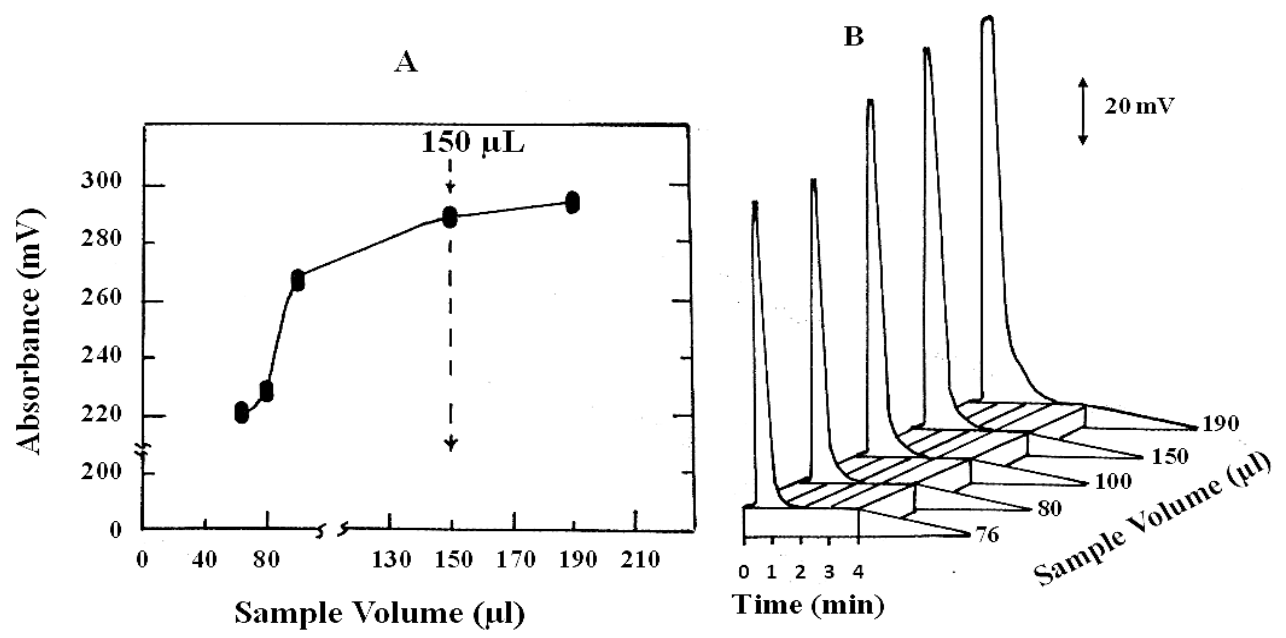

Fig. 9: Effect of variation of sample volume on:

A- Absorbance.

B- Response profile of Ayah 3SX3-3D solar FI photometer for pinkish-red species.

\section{- Effect of purge time:}

Using different purge time for the sample segment i.e. using 10 to 35 seconds allowed permissible time for the carrier solution to passing through the injection valve in injection mode followed by turning the injection valve to the load position. Sample volume of $150 \mu \mathrm{L}$ was used. Fig. 10 shows the continuation of the increase in absorbance with increase of injection time up to 20 seconds then followed by a decrease with the increase of injection time. The decrease in absorbance when using less than 20 seconds was attributed to the incomplete purge of the sample from sample loop in the injection valve. Above 20 seconds the decrease was attributed to the resistance of flow due to the passage through the injection valve, therefore 20 seconds as purge time was chosen as optimum time to the complete purge of the sample from sample loop.

\section{- Stability of the coloured species} with time:

Using the optimum parameters achieved at previous sections: promethazine- $\mathrm{HCl}\left(2 \mathrm{mmol} . \mathrm{L}^{-1}\right)-\mathrm{S}_{2} \mathrm{O}_{8}{ }^{2-}$

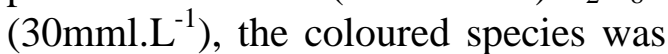
formed immediately and the stability of the colour product with respect time was depicted in fig. 11. in which absorbance were recorded starting from time $=10$ seconds up to $12 \mathrm{hr}$ shows that the coloured species were faded in colour starting at time $4 \mathrm{hrs}$, followed by a continuous decrease up to $10 \mathrm{hrs}$ where it completely disappears. 
The development of pinkishred colour that fades continuously is in accordance with the work of duchinski[20]who established that oxidation proceeds in two-1-electron stages. The first stage results simply from the loss of an electron from the parent compound and produced the corresponding free radical cation which is intensely pinkish-red. The second stage is a further 1-electron oxidation of the free radical to a colourless sulphoxide.

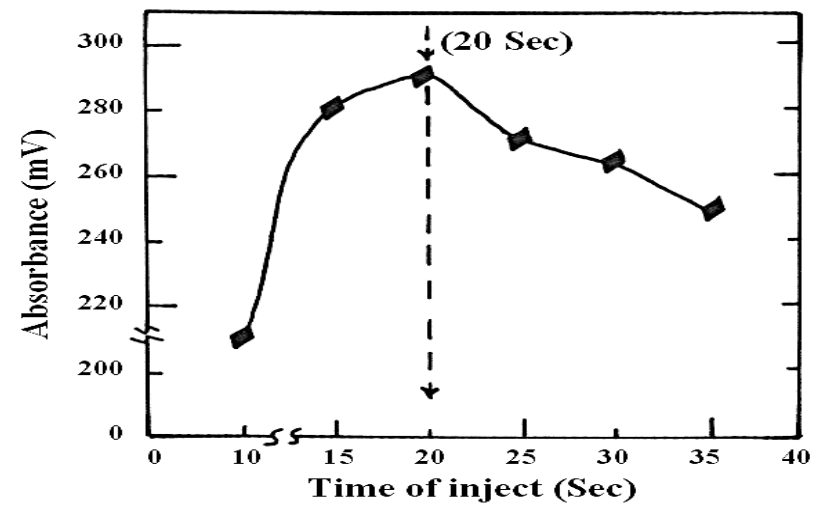

Fig. 10: Effect of variation of injection time on the oxidation of promethazine$\mathrm{HCl}$ with $\mathrm{S}_{2} \mathrm{O}_{8}{ }^{2-}$. Using optimum parameter: promethazine-HCl $\left(2 \mathrm{mmol} . \mathrm{L}^{-1}\right)$ $\mathrm{S}_{2} \mathrm{O}_{8}{ }^{2-}\left(30\right.$ mmol. $\left.\mathrm{L}^{-1}\right)$, flow rate $\left(1.5 \mathrm{ml} . \mathrm{min}^{-1}\right)$, sample volume $(150 \mu \mathrm{L})$.

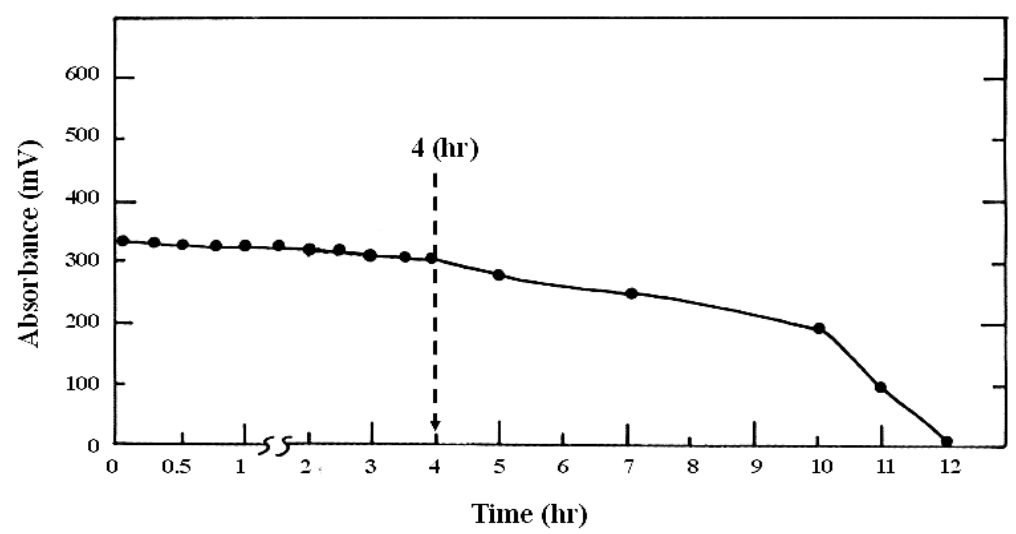

Fig. 11: Effect of time on stability of the colour species.

Variation of absorbance versus concentration of promethazine-HCl

Various concentrations $(0,0.03$, $0.05,0.1,0.3,0.5,0.7,1,2,3,5,7$ and $\left.10 \mathrm{mmol} . \mathrm{L}^{-1}\right)$ of promethazine- $\mathrm{HCl}$ were prepared by using the parameters established above. Each measurement was repeated three times. The absorbance of the average peak height $(\mathrm{mV})$ was plotted against the concentration of promethazine- $\mathrm{HCl}$, a straight-line graph (fig.12) from 0-7 mmol. $\mathrm{L}^{-1}$ of promethazine-HCl was obtained. Above $7 \mathrm{mmol} . \mathrm{L}^{-1}$ the value for correlation coefficient will deviate from linearity most probably due to the high intensity of the coloured species in front of detector. The obtained results were tabulated in table no. 1 . 
Table 1: Summery of calibration graph results for the determination of promethazine-HCl using sodium persulphate as oxidizing agent.

\begin{tabular}{|c|c|c|c|c|c|}
\hline \multirow[t]{2}{*}{$\begin{array}{c}\text { Measured } \\
\text { [promethazine- } \\
\mathrm{HCl} \text { ] mmol.L }{ }^{-1}\end{array}$} & \multirow{2}{*}{$\begin{array}{l}\text { Linear dynamic } \\
\text { range mmol. } \mathrm{L}^{-1} \\
\mathrm{n}=12\end{array}$} & \multirow[t]{2}{*}{$\begin{array}{c}\hat{\mathrm{y}}(\mathrm{mV})=\mathrm{a} \pm \mathrm{S}_{\mathrm{a}} \mathrm{t}+\mathrm{b} \pm \mathrm{S}_{\mathrm{b}} \mathrm{t}[\mathrm{x}] \mathrm{mmol}^{-\mathrm{L}^{-1}} \text { at } \\
\text { confidence interval at } 95 \%, \mathrm{n}-2\end{array}$} & \multirow[t]{2}{*}{$\mathrm{r}, \mathrm{r}^{2}$} & $\mathrm{t}_{\mathrm{tab}}$ & $t_{\mathrm{col}}=\frac{|r| \sqrt{n-2}}{\sqrt{1-r^{2}}}$ \\
\hline & & & & & at $95 \%, \mathrm{n}-2$ \\
\hline $0-10$ & $0-7$ & $61.79 \pm 28.83+107.85 \pm 10.61[\mathrm{X}] \mathrm{mmol} . \mathrm{L}^{-1}$ & \begin{tabular}{|c|}
0.9904 \\
$98.09 \%$
\end{tabular} & & $2.228<<22.67$ \\
\hline
\end{tabular}

$\mathrm{x}=$ promethazine-HCl.

Limit of detection for promethazine- $\mathrm{HCl}$ was conducted through four methods as tabulated in

table no. 2. at injected sample volume of $150 \mu \mathrm{L}$, also L.O.Q was reported.

Table 2: Limit of detection and limit of quantitation for promethazine-HCl at optimum parameter.

\begin{tabular}{|c|c|c|c|c|}
\hline $\begin{array}{c}\text { General dilution for } \\
\text { the minimum conc. }\end{array}$ & $\begin{array}{c}\text { Based on dilution } \\
\text { factor }(\mathrm{df})\end{array}$ & $\begin{array}{c}\text { Based on the value } \\
\text { of slope } x=\frac{\mathrm{as}}{\text { Slpos }_{\mathrm{B}}}\end{array}$ & $\begin{array}{c}\text { Linear equation } \\
\hat{\mathrm{y}}(\mathrm{mV})=\mathrm{y}_{\mathrm{B}}+3 \mathrm{~S}_{\mathrm{B}}\end{array}$ & L.O.Q= $\mathrm{y}(\mathrm{mV})=\mathrm{y}_{\mathrm{B}}+10 \mathrm{~S}_{\mathrm{B}}$ \\
\hline $0.2407 \mu \mathrm{g}$ & $0.0401 \mu \mathrm{g}$ & $0.402 \mu \mathrm{g}$ & $47.89 \mu \mathrm{g}$ & $3.97 \mu \mathrm{g}$ \\
\hline
\end{tabular}

$d f=6$

$x$ : value of L.O.D. based on slope

$S_{B}:$ standard deviation of blank solution

$y_{B}$ : average response for the blank solution (equivalent to intercept in straight line equation)

L.O.D: limit of detection

L.O.Q: limit of quantitation

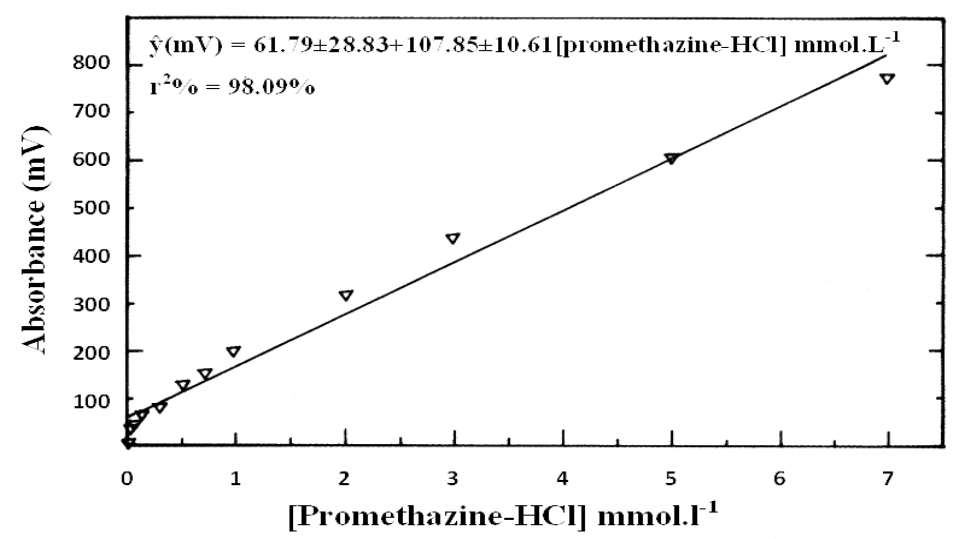

Fig. 12: Effect of variation of promethazine-HCl on absorbance at optimum conditions: promethazine-HCl (variation of conc.)- $\mathrm{S}_{2} \mathrm{O}_{8}{ }^{2-}\left(30 \mathrm{mmol} . \mathrm{L}^{-1}\right)$, flow rate: $1.5 \mathrm{ml} . \mathrm{min}^{-1}$, sample volume $150 \mu \mathrm{L}$, injection time $20 \mathrm{sec}$.

The repeatability was studied via measurements of R.S.D\% for some selected concentration of promethazine- $\mathrm{HCl}(\mathrm{n}=8)$ tabulated in table no. 3. The response profile at concentration $0.5,3 \mathrm{mmol} . \mathrm{L}^{-1}$ of eight successive injected sample measurements as shown in fig. 13.

Table 3: Repeatability of promethazine-HCl results.

\begin{tabular}{|c|c|c|c|}
\hline $\begin{array}{c}\text { [Promethazine-HCl] } \\
\text { mmol.L }\end{array}$ & $\bar{y}_{\mathrm{i}}(\mathrm{n}=8)(\mathrm{mV})$ & Repeatability RSD\% & $\begin{array}{c}\text { Confidence interval of the mean at } \\
95 \%\end{array}$ \\
\hline 0.5 & 130 & 0.68 & $\bar{y}_{i} \pm t_{0,025,1}^{*} \frac{\sigma_{n-1}}{\sqrt{n}}$ \\
\hline 2 & 270 & 0.99 & $270 \pm 0.74$ \\
\hline 3 & 440 & 0.30 & $440 \pm 1.67$ \\
\hline
\end{tabular}


B

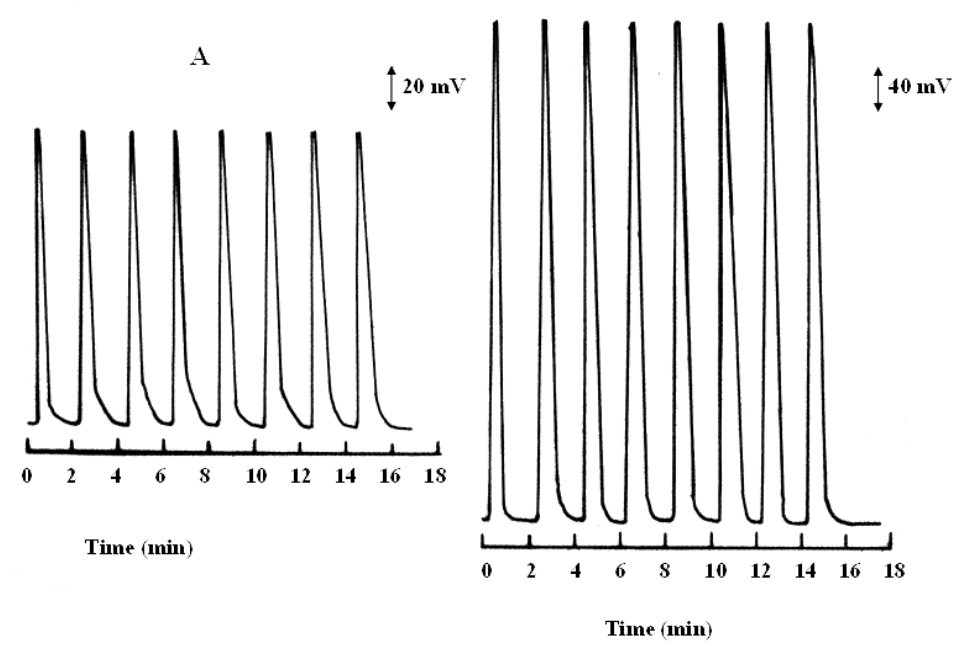

Fig. 13: Successive repeatable measurement for promethazine-HCl; A: 0.5 mmol.. $\mathbf{L}^{-1}$, B: 3 mmol... $\mathbf{L}^{-1}$.

Analysis of pharmaceutical
preparation
The proposed method achieved in this work was used for the analysis of promethazine- $\mathrm{HCl}$ in pharmaceutical preparation and was compared with the official method [21]. Thirteen tablets were weight, crushed and grinded. Tablets containing $25 \mathrm{mg}$ of promethazine- $\mathrm{HCl}$ were weighted $0.51396 \mathrm{gm}(96.27 \mathrm{mg}$ active ingredient) $\left(3 \mathrm{mmol} . \mathrm{I}^{-1}\right)$ from pharmaceutical preparation, dissolved in as a little water, followed by filtration to get rid of undissolved materials and completed the volume to $100 \mathrm{ml}$ with distilled water; $5 \mathrm{ml}$ drown to each of five $100 \mathrm{ml}$ volumetric flasks followed by the addition of gradual volumes of standard promethazine- $\mathrm{HCl}(0,1,1.5$, $2,2.5) \mathrm{ml}$ of $10 \mathrm{mmol} \cdot \mathrm{L}^{-1}$ to obtained $(0.15,0.25,0.3,0.35$, and 0.4$) \mathrm{mmol} . \mathrm{L}^{-}$ ${ }^{1}$. Flask no. 1. is the sample. The measurement was conducted by proposed method and the results were mathematically treated for the standard addition method. The results were tabulated in table no. 4. at confidence interval $95 \%$, paired t-test[22,23] was used as shown in table no. 5. The obtained results indicate clearly that there was no significant difference between newly developed method (FIA-Spectrophotometer) with official method[21] at 95\% confidence level because calculated $t$ value is less than tabulated $t$ value.

Table 4: Results for the determination of promethazine-HCl in pharmaceutical preparation using proposed method.

\begin{tabular}{|c|c|c|c|c|c|}
\hline $\begin{array}{c}\text { Commercial name, } \\
\text { content and country }\end{array}$ & $\begin{array}{c}\text { Confidence interval } \\
\text { for the average } \\
\text { weight at } 95 \% \\
\bar{w} \pm 1.96 \frac{\sigma_{n-1}}{\sqrt{n}}(\mathrm{~g})\end{array}$ & $\begin{array}{c}\text { Sample weight } \\
(4.8135 \mathrm{mg}) \\
\text { equivalent to } 0.15 \\
\text { mmol. } \mathrm{L}^{-1} \text { of active } \\
\text { ingredient }(\mathrm{g})\end{array}$ & $\begin{array}{c}\text { confidence interval } \\
\text { for the theoretical } \\
\text { content of active } \\
\text { ingredient at } 95 \% \\
\mathrm{n}=\infty(\mathrm{mg})\end{array}$ & $\begin{array}{c}\text { Practical content } \\
\text { of active } \\
\text { ingredient at } \\
95 \% \mathrm{n}=\infty(\mathrm{mg})\end{array}$ & $\begin{array}{c}\text { Recovery } \\
\%\end{array}$ \\
\hline $\begin{array}{c}\text { Histazine } 25 \mathrm{mg} \\
\begin{array}{c}\text { United pharmaceutical } \\
\text { Jordanie }\end{array}\end{array}$ & $0.1335 \pm 0.00088$ & 0.0257 & $25 \pm 0.1648$ & $24.6705 \pm 2.693$ & $98.68 \%$ \\
\hline
\end{tabular}


Table 5: Paired t-test results for FIA-Spectrophotometer proposed method with official method ${ }^{(21)}$ for determination of promethazine-HCl in pharmaceutical preparation.

\begin{tabular}{|c|c|c|c|c|c|}
\hline $\begin{array}{c}\text { Purposed method FIA- } \\
\text { spectrophotometer }(\overline{\mathbf{x}})\end{array}$ & $\begin{array}{c}\text { Official method } \\
\text { 'cuoted value' }(\mu)\end{array}$ & $\sigma_{m-1}$ & $\mathrm{n}$ & $\mid t_{\text {cal。 }} \mathrm{I}=\frac{(\bar{x}-\mu) \sqrt{n}}{S}$ & $\begin{array}{c}\mathrm{t}_{\text {tab }} \\
\text { at 95\%, } \mathrm{n}-1\end{array}$ \\
\hline $24.67 \mathrm{mg}$ & $25 \mathrm{mg}$ & 2.38 & 8 & $|-0.39|=0.39<<2.365$ \\
\hline
\end{tabular}

\section{Conclusion:}

A spectrophotometric FIA procedure is proposed for the determination of promethazine- $\mathrm{HCl}$ with application in the control analysis of pharmaceutical formulations. The method is based on the oxidation of promethazine- $\mathrm{HCl}$ with sodium persulphate to pinkish-red product. From the experimental point of view, the manipulation is very simple and sequential measurement was permitted with sample frequency up to 30 samples per hour. The proposed method uses cheaper instruments and reagents compared with classical spectrophotometry[6], flourometry and other FIA methods with different oxidizing reagents. In this paper a more effective faster determination was achieved by using Ayah 3SX3-3D solar FI photometer, light emitted diode as source with a detection using solar cell. The R.S.D $\%$ was $<1 \%$ observed for all samples, which is an indication of satisfactory precision of the proposed method. The standard addition method was used to avoid matrix effects. Also this method can be applied to micro determination of promethazine- $\mathrm{HCl}$ in pure as well as in pharmaceutical preparation and offers the advantages of high sensitivity without the need for heating or extraction. The statistical analyses are in good agreement with those of the British pharmacopoeia.

\section{References:}

1. Reynolds J. E. F. , Prasad A. B. and Martindale, 1982, the extra pharmacopoeia, pharmaceutical press, London, $28^{\text {th }}$ edn., pp. $1294-$ 1297.

2. Calatayud J. M and Mateo V. G., 1992, Cerium(IV) arsenite as a solid phase reactor for use in flowinjection analysis. Spectrophotometric determination of promethazine, Anal. Chim. Acta, 264, 283289.

3. Gowda H. S., Ramappa P. G. and Nayak A. N., 1979, Rapid spectrophotometric determination of phenothiazines with molybdophosphoric acid, Anal. Chim. Acta, 108: 277-283.

4. Basavaiah K., 2004, Indirect spectrophotometric determination of some biological important phenolthiazines using potassium dichromate, iron(II) and 1,10-phenanthroline, Indian J. Chem. Techn., 11: 632-638.

5. Revanasiddaappa H. D. and Ramappa P. G., 1996, Spectrophotometric determination of some phenothiazine drugs, Talanta, 43: 1291-1296.

6. Saif M. J. and Anwar J., 2005, A new spectrophotometric method for the determination of promethazine$\mathrm{HCl}$ from pure and pharmaceutical preparations, Talanta, 67: 869-872.

7. Sastry C. S. P., Prasad tipirneni A. S. R. and Suryanarayana M. V., 1990, spectrophotometric determination of some antiallergic agents with 3-metyl-2-benzothiazolinone hydrazone, J. pharm.Biomed.Anal., 8 (3): 287-292.

8. Alizadeh T. and Khoundian M. A., 2010, A novel potentiometric sensor for promethazine based on a 
molecularly imprinted polymer (MIP): the role of MIP structure on the sensor performance, Electrochim. Acta, 55:3477-3485.

9. Calatayud J. M., Sarrion S. N., Sampedro A. S.and Benito C. G., 1992, Determination of promethazine- $\mathrm{HCl}$ with bromophenol blue by a turbidimetric method and flow injection analysis, Microchem.J., 45:129-136.

10. Zhang Q., Zhan X., Li C., Lin T., Li L., Yin X., He N. and Shi Y., 2005, determination of promethazine- $\mathrm{HCl}$ and its preparations by highly accurate nephelometric titration, Intern. J. Pharm., 302:0-17.

11. Walash M. I., Belal F.and Aly F. A., 1988, Evaluation of certain pharmaceuticals with hexaamminecobalt (III) tricarbonatocobaltate (III), Talant, 35(4): 320322.

12. Czerniak A. S., Dembinski B. and Kurzawa M., 2001, spectrophotometric determination of 2and, 10-disubstituted phenothiazines, Acta Polon. Pharm.-Drug research, 58(4): 235-240.

13. Pena L. D., Gomez-Hens A. \& Perez-Bendito D., 1993, Kinetic flourimetric determination of promethazine by a stoped-flow mixing technique, J. Pharm. Biomed. Anal., 11(10): 893-896.

14. Sultan S. M., Hassan Y. A. M. and Abulkibash A. M., 2003, Chemiluminescence assay of promethazine- $\mathrm{HCl}$ using acidic permanganate employing flow injection mode operated with syringe and peristaltic pumps, Talanta, 59:1073-1080.

15. AlWarthan A.A., Al-Tamrah S.A. and Akel A.A.,1993,Determination of promethazine by its inhibition of chemiluminescence of the luminolhydrogen peroxide-chromium(III) system, Anal. Chim. Acta, 282,169-174.

16. Calatayud J. M. and Sancho T. G., 1992, Spectrophotometric determination of promethazine by flow injection analysis and oxidation by Ce(IV), J. pharm. Biomed. Anal., 10(1):37-42.

17. Michalowski J., Kojlo A., Magnuszewska B.and Trojanowicz M., 1994, Flow-injection biamperometry of phenothiazine derivatives, Anal. Chim. Acta, 289: 339-346.

18. Shakir I.M.A. and Turkey N. S, 30/ 8 /2012, Determination of metformin drug by single water crystal containing entrapped copper(II) ion with new photometric unit using LED with wave lengths 530 and $550 \mathrm{~nm}$, patent, Baghdad University, NO.3424,G01N29/00.

19. Smith J. G.,2006, Organic chemistry , McGraw Hill,1 ${ }^{\text {st }}$ edn. ,New York ,1003.

20. Duchinski G.andTurney T.A., 1965, oxidation Mechanisms, Butter Worths ,London ,198.

21. The Brithish pharmacopoeia, , 1993, Her majesty's stationary office, London, 1902.

22. Miller J. C.and Miller J. N., 1988, "Statistics for analytical chemistry", $2^{\text {nd }}$ Ed., John Willey \& N. Y. Sons, 65.

23. Murdoch J. and Barnes J. A,1974, "Statistical tables", $2^{\text {nd }}$ Ed. Macmillan,46. 


\section{التحليل بالحقن الجرياني للتقدير الطيفي للبروميثازين-هيدروكلورايد في

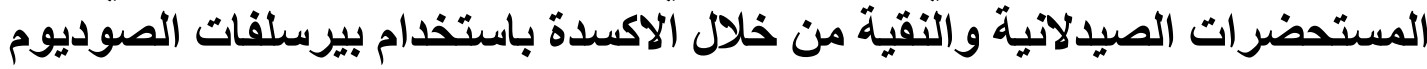

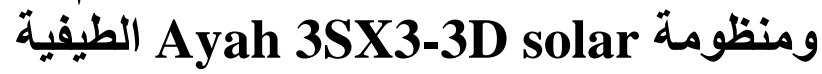<smiles></smiles>

عصام محمد علي شاكر*

|قشم الكيمياء - كلية العلوم - جامعة بغداد - العراق

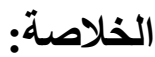

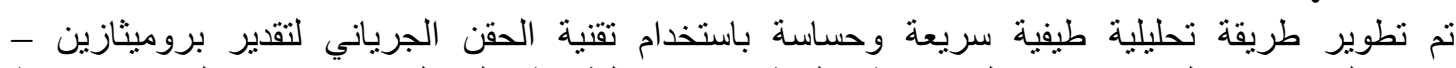

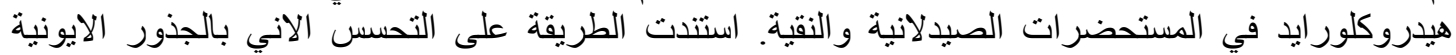

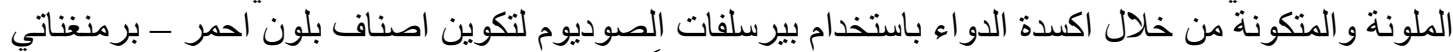

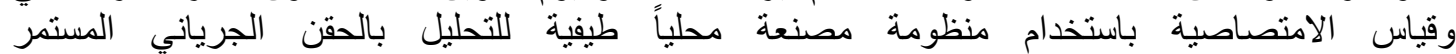
Ayah 3SX3-3D solar FI photometer

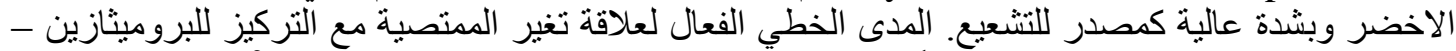

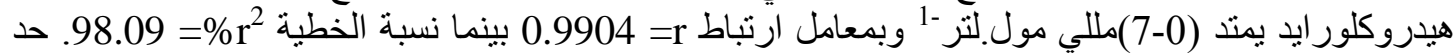

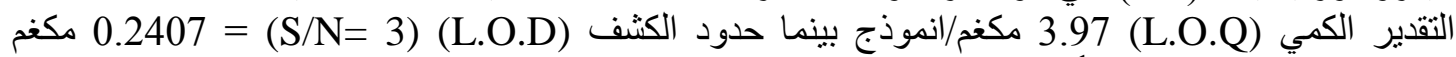

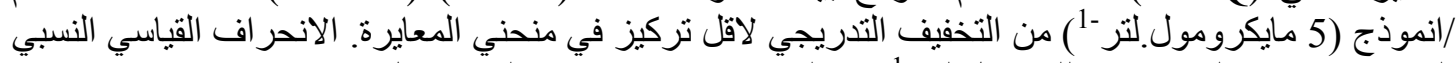

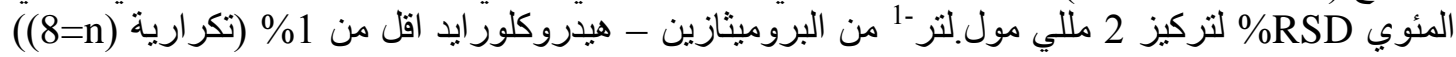

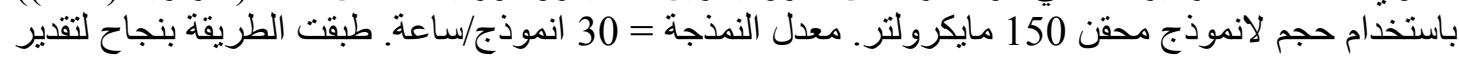

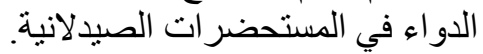

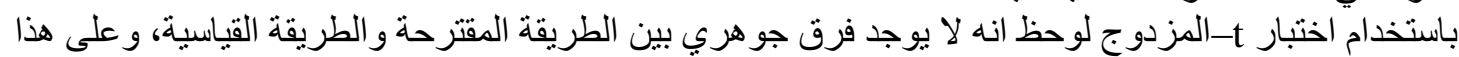
الاساس بالامكان استخدام الطريقة المقترحة للتحليل بالحقن الجرياني الطيفي كبديل للطريقة القياسية. 